\title{
PENINGKATAN KREATIVITAS GURU MELALUI PENGEMBANGAN SUPERVISI KEPALA SEKOLAH DAN IKLIM ORGANISASI
}

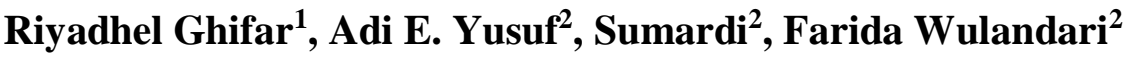 \\ ${ }^{1}$ Guru SDN Pancoran Mas Kota Depok \\ ${ }^{2}$ Program Pascasarjana Universitas Pakuan, \\ Email: pasca@unpak.ac.id
}

\begin{abstract}
The purpose of this study was to discover some effective efforts to increase teacher creativity by researching the relationship between school principal supervision and school organizational climate, with teacher's creativity. The research uses survey method with correlational approach. The population in this study were all 138 government teachers from 8 public school at Cluster 3 in Pancoran Mas sub-district, Depok City, West Java Province. The sample in this study was taken by proportional random sampling technique with the Slovin formula with a margin error of 5\% with a sample of 103 people. The conclusions are:1) There is positive, strong and significant correlation between the Principal Supervision and Creativity $\left(r_{y 1}=0.630, \alpha=0,01\right)$, with determination coefficient $r_{y 1}^{2}=$ 0.3969, means that the Principal Supervision contributes 39.69\% to Creativity, 2) There is positive, strong and significant relationship between the Organizational Climate and Creativity $\left(r_{y 2}=0.730, \alpha=0,01\right)$, with coefficient of determination $r_{y 2}^{2}=0.5329$, we can say that the Organizational Climate contributes $53.29 \%$ to Creativity, 3) There is positive, very strong and significant correlation between the Principal Supervision and Organizational Climate together with Creativity $\left(r_{y 12}=0,92, \alpha=0,01\right)$. Both go hand in hand which means that the higher the Supervision of the Principal and the Organizational Climate together, the higher the Creativity. The correlation between the two is indicated by the correlation coefficient ry. $12=0.920$ (Very Strong) and the coefficient of determination r2y.12=0.8464 which means that the Supervision of the Principal and Organizational Climate together contribute $84.64 \%$ to Creativity with the equation regression $=122.44+0.06 X 1+0.08 X 2$. means that each increase in one unit in the variables X1 and X2 will cause an increase of 0.06 and 0.09 units in variable $Y$.
\end{abstract}

Keywords: Principal Supervision, Organizational Climate, Creativity

\begin{abstract}
ABSTRAK
Penelitian ini bertujuan menemukan upaya-upaya meningkatkan kreativitas guru dan gambaran empiris studi tentang hubungan antara supervisi kepala sekolah dan iklim organisasi sekolah dengan kreativitas guru. Metode penelitian yang digunakan dalam penelitian ini adalah metode survei. Metode survei dengan pendekatan korelasional dilakukan terhadap sampel dari suatu populasi, kemudian menganalisa sampel, dan hasil analisa sampel diberlakukan untuk populasi. Populasi dalam penelitian ini adalah seluruh Guru PNS di SDN Se-Gugus 3 wilayah kecamatan Pancoran Mas Kota Depok Provinsi Jawa Barat yang berjumlah 138 orang dari 8 sekolah. Sampel diambil dengan teknik proporsional random sampling, dan dengan rumus Slovin didapat jumlah sampel 103 orang. Penelitian ini menghasilkan kesimpulan sebagai berikut: 1) Terdapat hubungan positif dan signifikan antara
\end{abstract}


Supervisi Kepala Sekolah dengan Kreativitas $\left.\left(\mathrm{r}_{\mathrm{y} 1}=0,630, \alpha=0,01\right) ; 2\right)$ Terdapat hubungan positif, dan kuat, dan signifikan antara Iklim Organisasi dengan Kreativitas $\left(\mathrm{r}_{\mathrm{y} 2}=0,730\right.$, $\alpha=0,01)$; 3) Terdapat hubungan positif yang sangat kuat, dan signifikan antara Supervisi Kepala Sekolah, dan Iklim Organisasi secara bersama-sama dengan Kreativitas $\left(\mathrm{r}_{\mathrm{y} 12}=\right.$ $0,920, \alpha=0,01)$.

Kata Kunci : Supervisi Kepala Sekolah, Iklim Organisasi, Kreativitas

\section{PENDAHULUAN}

Era globalisasi menuntut perubahan di segala aspek kehidupan manusia, termasuk dalam lingkungan pendidikan. Sebagai salah satu aspek yang krusial dalam pembentukan manusia, pendidikan diharapkan mampu menyesuaikan dirinya untuk mengejar cepatnya perubahan yang terjadi pada jaman modernisasi ini. Sekolah-sekolah yang mengutamakan kreaivitas yang diprediksi dapat bertahan dan unggul dalam persaingan di era digital. Karenanya setiap lembaga pendidikan wajib mengupayakan tumbuh kembangnya kreativitas guru khususnya dalam rangka meningkatkan kualitas proses pembelajaran yang bermuara pada optimalisasi output pendidikan.

Program penyelenggaraan kegiatan pendidikan dilakukan secara mandiri di era otonomi daerah, melalui kebijakan desentralisasi pendidikan yang bertujuan untuk mengurangi intervensi pusat dalam operasional pendidikan seraya mengembangkan pengelolaan berorintasi keunggulan, kreativitas dan kearifan lokal. Kebijakan ini juga bertujuan mendorong pengembangan iklim sekolah yang memastikan visi dan misi dapat tercapai, yaitu iklim sekolah yang menunjang produktivitas dan sekaligus memungkinkan kreativitas guru berkembang optimal dalam menunjuang tercapainya tujuan sekolah. Upaya meningkatkan kreativitas guru memerlukan bimbingan dan supervisi dari kepala sekolah berupa arahan atau pemberian contoh kepada guru mengenai bagaimana mempersiapkan, melaksanakan dan mengevaluasi pembelajaran yang kreatif inovatif.

\section{Kreativitas}

Menurut Yusuf dan Nurihsan (2015:247) kreativitas ditandai oleh adanya kegiatan menciptakan sesuatu yang sebelumnya tidak ada, dan tidak dilakukan oleh seseorang atau adanya kecenderungan untuk menciptakan sesuatu. Indikator dari kreativitas adalah: 1) Cara berpikir baru, 2) Ide baru, dan 3) Pikiran dan ide yang bermanfaat. Menurut Hellriegel dan Slocum (2011: 43) creativity is to visualize and implement new ideas or concept or new association between existing ideas or concept that are novel and useful. Jadi kreativitas adalah cara menvisualisasikan, menghasilkan dan menemukan ide-ide baru atau konsep baru yang mempunyai manfaat untuk orang lain. Indikator dari kreativitas adalah: 1) Ide-ide baru, 2) Konsep baru, 3) Menemukan sesuatu yang baru, dan 4) Menghasilkan sesuatu yang baru.

Colquitt et al. (2011:306-307) menyatakan bahwa kreativitas adalah penggunaan ideide baru dalam bekerja, memecahkan masalah dan melakukan tindakan-tindakan inovatif. Faktor-faktornya antara lain: 1) Senang mempelajari hal-hal baru, 2) Berupaya menemukan peluang atau cara-cara baru yang lebih baik dalam bekerja, 3) Keyakinan dalam bekerja, dan 4) Keterbukaan dalam menemukan ide-ide baru yang lebih baik. Individu kreatif pada dasarnya senang mempelajari hal-hal baru sehingga dapat menciptakan ide-ide baru dan diterapkan dalam bentuk tindakan-tindakan inovatif dengan penuh keyakinan, tetapi tidak menutup kemungkinan untuk terbuka menerima ide-ide baru lain untuk dijadikan peluang-peluang atau cara- cara baru yang lebih baik.

Berdasarkan teori di atas, dapat dibuat sintesis bahwa kreativitas adalah mewujudkan ide-ide baru dalam bekerja, memecahkan masalah dan melakukan tindakan-tindakan inovatif dengan pendekatan yang unik untuk memecahkan masalah dengan menggunakan 
teknologi dan sumber daya lainnya ke dalam proses yang unik yang membedakan prestasi dari setiap orang dalam organisasi.

\section{Supervisi kepala sekolah}

Suhardan (2010:35-41) mengemukakan tentang pengertian supervisi berdasarkan pembentukan kata yang merujuk pada sebuah aktivitas akademik, yaitu kegiatan pengawasan yang dijalankan oleh orang yang memiliki pengetahuan lebih tinggi dan lebih dalam dengan tingkat kepekaan yang tajam dalam memahami objek pekerjaannya dengan hati yang jernih. Mathori (2007:2) menjelaskan bahwa supervisi bertujuan untuk memelihara atau mengadakan perubahan operasional sekolah, dengan cara mempengaruhi tenaga pengajar secara langsung demi meningkatkan efektivitas kegiatan belajar siswa. Supervisi tidak hanya berhubungan langsung dengan guru, tetapi berkaitan pula dengan siswa dalam proses belajar.

Pengertian lain disampaikan Siagian (2003:135) yang menyatakan bahwa supervisi adalah proses pengamatan atas pelaksanaan seluruh kegiatan organisasi untuk menjamin agar semua pekerjaan yang sedang dilakukan berjalan sesuai dengan rencana yang telah ditentukan sebelumnya. Sejalan dengan hal tersebut Handayaningrat (2001:143) merumuskan supervise sebagai suatu proses di mana pimpinan ingin mengetahui apakah hasil pelaksanaan pekerjaan yang dilakukan oleh bawahannya sesuai dengan rencana, perintah, tujuan, atau kebijaksanaan yang telah ditentukan.

Dari uraian di atas dapat disimpulkan bahwa supervisi kepala sekolah adalah usaha yang dilakukan oleh seorang kepala sekolah untuk menjamin tujuan-tujuan sekolah dan manajemen sekolah tercapai. Indikator dari supervisi kepala sekolah adalah: a. Membimbing, b. Membantu, c. Melatih, dan d. Memotivasi.

\section{Iklim Organisasi}

Wirawan (2008:125) menyatakan bahwa istilah iklim (climate) adalah pengaruh ke seluruh sistem dari kelompok manusia atau organisasi, mencakup perasaan dan sikap sebagai suatu sistem, sub-sistem, superordinat sistem atau sistem pribadi, tugas-tugas, prosedur atau konsep-konsep. Pengertian organisasi menurut Siagian (2008:20) adalah setiap bentuk persekutuan antara dua orang atau lebih yang bekerja sama untuk mencapai tujuan bersama, dan terikat secara formal dalam satu ikatan hierarki di mana selalu terdapat hubungan antara seorang atau kelompok orang yang disebut pimpinan dan seorang atau kelompok orang yang disebut bawahan.

Anoraga (2010:58) menyatakan iklim organisasi adalah suasana kerja yang baik dan akan membawa pengaruh yang baik pula pada segala pihak, baik pada pekerja, pimpinan ataupun pada hasil pekerjaannya. Selanjutnya Soetisna (2010:117) menyatakan iklim organisasi adalah gabungan persepsi anggota suatu organisasi terhadap aspek- aspek ruang lingkup pekerjaannya yang mempengaruhi motivasi dan perilaku pegawai khususnya, budaya organisasi, jenis landasan kepemimpinan, tingkatan struktur, dan kebijakan serta praktikpraktik personalia.

Berdasarkan teori-teori di atas, dapat disimpulkan bahwa iklim organisasi sekolah adalah suasana lingkungan kerja tempat bekerja guru yang mempengaruhi guru dan karyawan dalam melaksanakan tugas-tugas di sekolah. Indikator yang berhubungan dengan iklim organisasi sekolah adalah: 1) Sarana dan prasarana yang memadai, 2) Suasana kerja, 3) Lingkungan eksternal organisasi, dan 4) Pengelolaan manajemen.

\section{METODE PENELITIAN}

Metode penelitian yang digunakan dalam penelitian ini adalah metode survey dengan pendekatan korelasional. Populasi penelitian ini adalah semua guru PNS berasal dari 8 SDN se-gugus 3 wilayah Kecamatan Pancoran Mas Kota Depok Propinsi Jawa Barat sejumlah 138 
orang. Sampel dalam penelitian ini diambil dengan teknik proporsional random sampling, dengan rumus Slovin diperoleh sampel 103 guru. Data diperoleh melalui instrument yang sudah teruji validitas dan reliabilitasnya.

\section{HASIL PENELITIAN}

\section{Pengujian persyaratan analisis}

\section{Uji Normalitas}

Pengujian normalitas dilakukan terhadap galat taksiran regresi $\mathrm{Y}$ atas $\mathrm{X}_{1}$, dan $\mathrm{Y}$ atas $\mathrm{X}_{2}$ dengan menggunakan statistik Uji Lilliefors. Pengujian galat taksiran regresi $\mathrm{Y}$ atas $\mathrm{X}_{1}$ menghasilkan nilai $\mathrm{L}_{\text {hitung }}$ maksimum sebesar 0,070 sedangkan $\mathrm{L}_{\text {tabel }}$ pada taraf nyata alpha 0,05 diperoleh nilai sebesar 0,087 . Ternyata $L_{\text {hitung }}<L_{\text {tabel }}$ atau $0,070<0,087$. Dengan demikian dapat disimpulkan bahwa galat taksiran $\mathrm{Y}$ atas $\mathrm{X}_{1}$ berdistribusi normal.

Untuk pengujian galat taksiran regresi $\mathrm{Y}$ atas $\mathrm{X}_{2}$ menghasilkan nilai $\mathrm{L}_{\text {hitung }}$ maksimum sebesar 0,067 sedangkan $\mathrm{L}_{\text {tabel }}$ pada taraf nyata alpha 0,05 diperoleh nilai sebesar 0,087 . Ternyata $\mathrm{L}_{\text {hitung }}<\mathrm{L}_{\text {tabel }}$ atau $0,067<0,087$. Dengan demikian dapat disimpulkan bahwa galat taksiran $\mathrm{Y}$ atas $\mathrm{X}_{2}$ juga berdistribusi normal. Oleh karena itu galat taksiran $\mathrm{Y}$ atas $\mathrm{X}_{1}$ dan $\mathrm{Y}$ atas $\mathrm{X}_{2}$ berdistribusi normal. Dengan demikian pengujian hipotesis yang menggunakan analisis korelasi dan regresi dapat dilakukan.

\section{Uji homogenitas}

Pengujian homogenitas dilakukan dengan maksud untuk mengetahui apakah sebaran data dari setiap variabel tidak menyimpang dari ciri-ciri data yang homogen. Pengujian homogen dilakukan terhadap varians regresi $\mathrm{Y}$ atas $\mathrm{X}_{1}$ dan $\mathrm{Y}$ atas $\mathrm{X}_{2}$ dilakukan dengan menggunakan uji Bartlett. Untuk pengujian varians regresi $\mathrm{Y}$ atas $\mathrm{X}_{1}$ menghasilkan nilai $\chi^{2}$ hitung sebesar 0,32 sedangkan $\chi^{2}$ tabel pada taraf nyata alpha 0,05 diperoleh nilai sebesar 3,91. Ternyata $\chi^{2}$ hitung $<\chi^{2}$ tabel atau $0,32<3,91$. Dengan demikian dapat disimpulkan bahwa varians $\mathrm{Y}$ atas $\mathrm{X}_{1}$ homogen.

Pengujian varians regresi $\mathrm{Y}$ atas $\mathrm{X}_{2}$ menghasilkan nilai $\chi^{2}$ hitung sebesar 0,67 sedangkan $\chi_{\text {tabel }}^{2}$ pada taraf nyata alpha 0,05 diperoleh nilai sebesar 3,91. Ternyata $\chi^{2}$ hitung $<\chi_{\text {tabel }}^{2}$ atau $0,67<3,91$. Dengan demikian dapat disimpulkan bahwa varians $\mathrm{Y}$ atas $\mathrm{X}_{2}$ homogen. Secara keseluruhan varians regresi $\mathrm{Y}$ atas $\mathrm{X}_{1}$ dan $\mathrm{Y}$ atas $\mathrm{X}_{2}$ dapat dinyatakan homogen. Dengan demikian pengujian hipotesis dengan menggunakan analisis korelasi dan regresi dapat dilakukan.

\section{Pengujian hipotesis}

\section{Hubungan antara Supervisi Kepala Sekolah $\left(X_{1}\right)$ Dengan Kreativitas Guru (Y)}

Berdasarkan hasil analisis regresi linear sederhana antara pasangan data Supervisi Kepala Sekolah (variabel $\mathrm{X}_{1}$ ) dengan Kreativitas Guru (variabel Y), diperoleh persamaan regresi antara variabel Supervisi Kepala Sekolah dengan Kreativitas Guru, $\hat{Y}=131,36+$ $0,07 \mathrm{X}_{1}$. Berdasarkan hasil analisis varians (uji-F), persamaan ini terbukti linear dan signifikan karena $F_{\text {hitung }}(1,72)<\mathrm{F}_{\text {tabel }}(1,77)$.

Peneiltian ini menemukan koefisien korelasi antara supervise kepala sekolah dengan kreativitas guru $\left(\mathrm{r}_{\mathrm{y} 1}\right)$ sebesar 0,630 . Nilai probabilitas $0,000<0,05$ dan 0,01 menunjukkan koefisien korelasi tersebut sangat signifikan. Dengan demikian penelitian ini mengkonfirmasi bahwa terdapat hubungan positif, dengan kekuatan sedang, dan sangat signifikan antara supervisi kepala sekolah dengan kreativitas guru. Kontribusi supervise kepala sekolah terhadap kreativitas guru $\left(\mathrm{r}^{2} \mathrm{y1}\right)$ sebesar 0,397 dapat dimaknai bahwa 39,7\% keragaman pada kreativitas guru dapat dijelaskan oleh factor supervisi kepala sekolah. 


\section{Hubungan antara Iklim Organisasi $\left(\mathbf{X}_{2}\right)$ Dengan Kreativitas Guru (Y)}

Berdasarkan hasil analisis regresi linear sederhana antara pasangan data iklim organisasi (variabel $\mathrm{X}_{2}$ ) dengan Kreativitas Guru (variabel $\mathrm{Y}$ ), diperoleh persamaan regresi $\hat{\mathrm{Y}}=130,25$ $+0,09 X_{2}$, dimana berdasarkan hasil analisis varians (uji-F), persamaan ini terbukti linear dan signifikan karena $F_{\text {hitung }}(1,26)<F_{\text {tabel }}(1,58)$.

Peneiltian ini menemukan koefisien korelasi antara supervise kepala sekolah dengan kreativitas guru $\left(\mathrm{r}_{\mathrm{y} 2}\right)$ sebesar 0,73 . Nilai probabilitas $0,000<0,05$ dan 0,01 menunjukkan koefisien korelasi tersebut sangat signifikan. Dengan demikian penelitian ini mengkonfirmasi bahwa terdapat hubungan positif, dengan kekuatan cukup kuat, dan sangat signifikan antara iklim organisasi dengan kreativitas guru. Kontribusi iklim organisasi terhadap kreativitas guru $\left(\mathrm{r}^{2}{ }_{\mathrm{y} 2}\right)$ sebesar 0,5329 dapat dimaknai bahwa 53,29\% keragaman pada kreativitas guru dapat dijelaskan oleh faktor iklim organisasi.

\section{Hubungan antara Supervisi Kepala Sekolah $\left(\mathbf{X}_{1}\right)$ Dan Iklim Organisasi $\left(\mathbf{X}_{2}\right)$ Secara Bersama-Sama Dengan Kreativitas Guru (Y)}

Berdasarkan hasil analisis regresi ganda antara pasangan data Supervisi Kepala Sekolah (variabel $X_{1}$ ) dan Iklim Organisasi (variabel $X_{2}$ ) secara bersama-sama dengan Kreativitas Guru (variabel $Y$ ), diperoleh persamaan regresi, yaitu $\hat{Y}=122,44+0,06 X_{1}+0,08 X_{2}$ yang teruji linearitas dan signifikansinya sehingga model persamaan garis regresi tersebut dapat digunakan untuk menarik kesimpulan mengenai hubungan supervise kepala sekolah dan iklim organisasi secara bersama-sama dengan kreativitas.

Analisis korelasi ganda menghasilkan koefisien korelasi ganda $r_{\mathrm{y} .12}$ sebesar 0,920 , berarti Supervisi Kepala Sekolah dan Iklim Organisasi secara bersama-sama mempunyai hubungan yang positif yang kuat dengan Kreativitas Guru. Dengan demikian berarti makin baik Supervisi Kepala Sekolah dan makin tinggi Iklim Organisasinya, makin tinggi pula Kreativitas Guru tersebut. Besarnya sumbangan variabel Supervisi Kepala Sekolah dan Iklim Organisasi terhadap Kreativitas Guru secara bersama-sama adalah 0,8464, artinya sumbangan Supervisi Kepala Sekolah dan Iklim Organisasi secara bersama-sama terhadap Kreativitas Guru adalah 84,64\%, sementara 15,36\% lainnya dipengaruhi oleh variabel lain yang tidak diamati dalam penelitian ini.

\section{Korelasi parsial}

Analisis korelasi parsial dilakukan antara variabel $\mathrm{Y}$ dengan variabel $\mathrm{X}_{2}$ dalam kondisi variabel $\mathrm{X}_{1}$ dikontrol (tetap). Hasil perhitungan memperoleh besaran $\mathrm{r}_{\mathrm{y} 2-1}$ sebesar 0,506. Uji signifikansi koefisien korelasi parsial $r_{y 2-1}$ menggunakan statistik uji " $t$ " dan memperoleh hasil thitung sebesar 8,346. Besaran ini dikonsultasikan $t_{\text {tabel }}$ dalam taraf nyata alpha 0,01 ; diperoleh besaran $t$ sebesar 2,617 atau $t_{\text {hitung }}>t_{\text {tabel. }}$. Dengan demikian koefisien korelasi parsial dapat dinyatakan sangat signifikan. Artinya Iklim Organisasi memberikan kontribusi yang berarti terhadap peningkatan Kreativitas Guru.

Analisis korelasi parsial dilakukan antara variabel $\mathrm{Y}$ dengan variabel $\mathrm{X}_{2}$ dalam kondisi variabel $\mathrm{X}_{1}$ dikontrol (tetap). Hasil perhitungan memperoleh besaran $\mathrm{r}_{\mathrm{y} 2-1}$ sebesar 0,506 . Uji signifikansi koefisien korelasi parsial $r_{\mathrm{y} 2-1}$ menggunakan statistik uji " $\mathrm{t}$ " dan memperoleh hasil $t_{\text {hitung }}$ sebesar 8,346. Besaran ini dikonsultasikan $t_{\text {tabel }}$ dalam taraf nyata alpha 0,01 ; diperoleh besaran $\mathrm{t}$ sebesar 2,617 atau $t_{\text {hitung }}>\mathrm{t}_{\text {tabel. }}$. Dengan demikian koefisien korelasi parsial dapat dinyatakan sangat signifikan. Artinya Iklim Organisasi memberikan kontribusi yang berarti terhadap peningkatan Kreativitas Guru. 


\section{PEMBAHASAN}

\section{Hubungan Antara Supervisi Kepala Sekolah Dengan Kreativitas Guru}

Pengujian hipotesis pertama menyimpulkan bahwa terdapat hubungan positif yang sangat signifikan antara Supervisi Kepala Sekolah dengan Kreativitas Guru, dimana pola hubungan antara kedua variabel ini dinyatakan oleh persamaan regresi $\hat{Y}=131,36+0,07 \mathrm{X}_{1}$. Persamaan ini memberikan informasi bahwa setiap perubahan satu tingkat Supervisi Kepala Sekolah akan dapat mengakibatkan terjadinya perubahan Kreativitas Guru sebesar 0,07 pada konstanta 131,36.

Hasil analisis korelasi sederhana antara Supervisi Kepala Sekolah dengan Kreativitas Guru diperoleh nilai koefisien korelasi $r_{y 1}=0,630$. Nilai ini memberikan pengertian bahwa keterkaitan antara Supervisi Kepala Sekolah dengan Kreativitas Guru tergolong cukup dan positif, artinya makin baik Supervisi Kepala Sekolah makin tinggi pula Kreativitas Guru tersebut. Demikian pula sebaliknya, makin kurang baik Supervisi Kepala Sekolah, makin rendah pula Kreativitas Gurunya.

Menurut Hellriegel dan Slocum (2011: 43) creativity is to visualize and implement new ideas or concept or new association between existing ideas or concept that are novel and useful. Jadi kreativitas guru adalah cara menvisualisasikan, menghasilkan dan menemukan ide-ide baru atau konsep baru yang mempunyai manfaat untuk orang lain. Indikator dari Kreativitas Guru adalah: 1) Ide-ide baru, 2). Konsep baru, 3) c. Menemukan sesuatu yang baru, dan 4) Menghasilkan sesuatu yang baru.

Mulyasa (2004:111) menyatakan bahwa "Supervision is a learn more about their practice; to better able to use their knowledge and skills to better serve parents and schools; and to make the school more effective learning community". Pengawasan adalah suatu proses yang dirancang untuk membantu guru dan pengawas mempelajari lebih lanjut tentang praktek mereka, untuk lebih mampu menggunakan pengetahuan dan keterampilan mereka untuk melayani orang tua dan sekolah, dan untuk membuat komunitas pembelajaran yang lebih efektif di sekolah.

Kreativitas Guru sangat diperlukan dalam meningkatkan mutu dan kualitas layanan pendidikan, karena hal ini berkaitan erat dengan keberhasilan pembelajaran dikelas, guru yang kreatif akan berusaha menciptakan pembelajaran yang efektif dan menyenangkan, apabila hal ini bisa dilakukan maka proses pembelajaran akan menghasilkan hasil yang maksimal. Kreativitas Guru berkaitan erat dengan supervisi kepala sekolah. Seorang pemimpin atau kepala sekolah yang mempunyai kharisma, menjadi panutan bawahannya, selalu memberi inspirasi dan motivasi akan sangat mempengaruhi Kreativitas Guru, karena guru diberi banyak kesempatan untuk mengembangkan ide-ide yang dimilikinya serta memfasilitasi mereka untuk mengembangkan ide atau gagasan mereka.

Kepala sekolah yang mempunyai peran sangat penting dalam mendukung setiap ide atau gagasan yang muncul dari para guru untuk pengembangan pembelajaran, sehingga Kreativitas Guru dapat berkembang seluas-luasnya dan dapat meningkatkan mutu dan kualitas pendidikan yang ada di sekolah tersebut.

Penelitian lain yang mendukung hasil penelitian ini adalah studi yang dilakukan oleh Yaping Gong (2009:33), yang menyimpulkan terdapat hubungan supervise dan kreativitas guru $(\mathrm{r}=0.73 \mathrm{p}<0.05)$.

\section{Hubungan Antara Iklim Organisasi Dengan Kreativitas Guru}

Pengujian hipotesis kedua menyimpulkan bahwa terdapat hubungan positif yang sangat signifikan antara Iklim Organisasi dengan Kreativitas Guru yang ditunjukkan oleh nilai $t_{\text {hitung }}$ sebesar 8,697 jauh lebih besar dari pada nilai tabel pada taraf signifikansi alpha 0,01 yaitu 2,617 atau $\mathrm{t}=8,697>2,617$. Pola hubungan antara kedua variabel ini dinyatakan oleh persamaan regresi $\hat{Y}=130,25+0,09 X_{2}$. Persamaan ini memberikan informasi bahwa setiap 
perubahan satu unit skor Iklim Organisasi akan mengakibatkan terjadinya perubahan skor Kreativitas Guru sebesar 0,09 pada konstanta 130,25.

Hasil analisis korelasi sederhana antara Iklim Organisasi dengan Kreativitas Guru diperoleh nilai koefisien korelasi $\mathrm{r}_{\mathrm{y} 2}$ sebesar 0,730. Nilai ini memberikan pengertian bahwa keterkaitan antara Iklim Organisasi dengan Kreativitas Guru cukup dan positif, artinya makin tinggi Iklim Organisasi akan makin tinggi pula Kreativitas Guru tersebut. Demikian pula sebaliknya, makin rendah Iklim Organisasi, makin rendah pula Kreativitas Guru tersebut.

Besarnya sumbangan atau kontribusi variabel Iklim Organisasi terhadap Kreativitas Guru dapat diketahui dengan jalan mengkuadratkan nilai koefisien korelasi sederhananya. Hasil pengkuadratan nilai koefisien korelasi sederhananya adalah sebesar 0,5329. Secara statistik nilai ini memberikan pengertian bahwa kurang lebih 53,29 persen variansi perubahan Kreativitas Guru ditentukan/dijelaskan oleh Iklim Organisasinya dengan pola hubungan fungsionalnya seperti ditunjukkan oleh persamaan regresi tersebut di atas. Artinya jika SDN Gugus 3 Kecamatan Pancoran Mas Kota Depok diukur Iklim Organisasi dan Kreativitas Gurunya, maka variasi pasangan skor kedua variabel tersebut akan berdistribusi dan mengikuti pola hubungan antara variabel Iklim Organisasi dengan Kreativitas Guru melalui persamaan garis regresi $\hat{Y}=130,25+0,09 X_{2}$.

Colquitt et al. (2011:306-307) menyatakan bahwa Kreativitas Guru adalah penggunaan ide-ide baru dalam bekerja, memecahkan masalah dan melakukan tindakan-tindakan inovatif. Faktor-faktornya antara lain: 1). Senang mempelajari hal-hal baru, 2). Berupaya menemukan peluang atau cara-cara baru yang lebih baik dalam bekerja, 3) Keyakinan dalam bekerja, dan 4). Keterbukaan dalam menemukan ide-ide baru yang lebih baik. Individu kreatif pada dasarnya senang mempelajari hal-hal baru sehingga dapat menciptakan ide-ide baru dan diterapkan dalam bentuk tindakan-tindakan inovatif dengan penuh keyakinan, tetapi tidak menutup kemungkinan untuk terbuka menerima ide-ide baru lain untuk dijadikan peluangpeluang atau cara-cara baru yang lebih baik.

Wirawan (2008:122) mendefinisikan bahwa iklim organisasi sebagai suatu konsep yang melukiskan sifat subyektif atau kualitas lingkungan organisasi. Unsur-unsurnya dapat dipersepsikan dan dialami oleh anggota organisasi dan dilaporkan melalui kuesioner yang tepat. Iklim organisasi sekolah yang kondusif akan berdampak terhadap suasana kerja yang menyebabkan ide atau gagasan yang dimiliki guru dapat tersalurkan dengan baik, mendapat dukungan dari berbagai pihak terutama sekolah dan kepala sekolah, guru yang mempunyai motivasi tinggi akan menuangkan setiap ide yang dimilikinya untuk kemajuan sekolah sehingga motivasi untuk berprestasi sangat diperlukan, karena dari guru-guru inilah akan banyak muncul Kreativitas Guru baru yang akan membawa perubahan untuk sekolah

Penelitian yang memperkuat hasil penelitian adalah hasil penelitian Muge Leyla (2014:31), menghasilkan nilai korelasi antara Creativity dengan indikator-indikator Organizational Climate $(r=0563$ dan $r=0.753 p<0.01)$. Hal ini menunjukkan bahwa iklim organisasi berhubungan dengan Kreativitas Guru.

\section{Hubungan antara Supervisi Kepala Sekolah dan Iklim Organisasi Secara Bersama-sama Dengan Kreativitas Guru}

Pengujian hipotesis menyimpulkan terdapat hubungan positif yang sangat signifikan antara Supervisi Kepala Sekolah dan Iklim Organisasi secara bersama-sama dengan Kreativitas Guru yang ditunjukkan oleh nilai $F_{\text {hitung }}$ sebesar 0,418 . Pola hubungan dinyatakan oleh persamaan regresi ganda $\hat{Y}=122,44+0,06 X_{1}+0,08 X_{2}$. Persamaan ini memberikan informasi bahwa setiap perubahan satu unit skor Supervisi Kepala Sekolah dan Iklim Organisasi akan mengakibatkan terjadinya perubahan Kreativitas Guru sebesar 0,06 atau 0,08 . 
Hasil analisis korelasi ganda antara Supervisi Kepala Sekolah dan Iklim Organisasi diperoleh nilai koefisien korelasi ganda sebesar $r_{y .12}$ sebesar 0,920. Nilai ini menunjukkan bahwa keterkaitan antara Supervisi Kepala Sekolah dan Iklim Organisasi secara bersamasama dengan Kreativitas Guru cukup dan positif.

Supriadi (2010: 7) menyatakan bahwa Kreativitas Guru adalah melahirkan sesuatu yang baru, baik berupa gagasan maupun karya nyata, yang relatif berbeda dengan apa yang telah ada sebelumnya. Kreativitas Guru meliputi baik ciri-ciri aptitude seperti kelancaran (fluency), keluwesan (flexibility), dan keaslian (originality) dalam pemikiran, maupun ciri-ciri non aptitude, seperti rasa ingin tahu, senang mengajukan pertanyaan dan selalu ingin mencari pengalaman-pengalaman baru. Indikator dari Kreativitas Guru adalah: 1). Kelancaran adalah kemampuan menghasilkan banyak gagasan, 2) Keluwesan adalah kemampuan untuk mengemukakan bermacam-macam pemecahan atau pendekatan terhadap masalah, 3) Keaslian adalah kemampuan untuk mencetuskan gagasan dengan cara-cara yang asli, tidak klise, 4). Elaborasi adalah kemampuan untuk menguraikan sesuatu secara terperinci, dan 5) Redefinisi adalah kemampuan untuk meninjau suatu persoalan berdasarkan perspektif yang berbeda dengan apa yang sudah diketahui oleh banyak orang.

Handayaningrat (2001:143) memberikan definisi supervisi sebagai proses di mana pimpinan ingin mengetahui apakah hasil pelaksanaan pekerjaan yang dilakukan oleh bawahannya sesuai dengan rencana, perintah, tujuan, atau kebijaksanaan yang telah ditentukan. Sementara Anoraga (2010:58) menyatakan iklim organisasi sekolah atau suasana kerja di sekolah adalah suasana kerja yang baik dan akan membawa pengaruh yang baik pula pada segala pihak, baik pada pekerja, pimpinan ataupun pada hasil pekerjaannya. Selanjutnya Soetisna (2010:117) menyatakan iklim organisasi adalah gabungan persepsi anggota suatu organisasi terhadap aspek-aspek ruang lingkup pekerjaannya yang mempengaruhi motivasi dan perilaku pegawai khususnya, budaya organisasi, jenis landasan kepemimpinan, tingkatan struktur, dan kebijakan serta praktik-praktik personalia.

Kreativitas Guru berkaitan erat dengan pribadi guru tersebut, seorang pribadi yang kreatif, mempunyai ide atau gagasan baru terutama dalam hal proses belajar mengajar di sekolah, seorang guru yang kreatif akan mencoba menciptakan model pembelajaran baru, model penilaian yang disesuaikan dengan karakteristik siswa atau bahkan muncul ide baru ketika menghadapi permasalahan di kelas atau sekolah, mereka selalu mempunyai gagasan untuk mengembangkan program-program sekolah.

Iklim organisasi sekolah yang positif akan mendorong guru lebih kreatif, karena guru merasa leluasa menyampaikan gagasannya tanpa merasa perlu dikitrik. Kreativitas Guru dipengaruhi juga oleh supervisi kepala sekolah, karena seorang pemimpin yang bisa menjadi panutan bawahan, selalu menginspirasi dan memotivasi bawahan merupakan faktor yang sangat mempengaruhi Kreativitas Guru di sekolah tersebut, guru akan bebas mengekspresikan semua ide atau gagasan yang dimiliki, dengan dukungan dari kepala sekolah sehingga Kreativitas Guru akan berkembang dengan baik dan bisa dikembangkan untuk mencapai tujuan organisasi sekolah tersebut.

Kedua variabel tersebut diduga memberikan kontribusi terhadap Kreativitas Guru, karena dengan iklim organisasi sekolah, seorang guru akan mempunyai keinginan berkompetisi dalam segala hal, sehingga akan menghasilkan Kreativitas Guru baru baik dalam proses belajar mengajar maupun dalam bidang lainnya. Demikian pula dengan supervisi kepala sekolah, perilaku dan karakter kepala sekolah dengan gaya disiplin kerja dengan melakukan supervisi ini akan mendukung Kreativitas Guru-guru tersebut.

Dengan demikian berarti makin baik Supervisi Kepala Sekolah dan Iklim Organisasi, maka semakin tinggi pula Kreativitas Guru. Sebaliknya makin kurang baik Supervisi Kepala Sekolah dan Iklim Organisasi seorang, maka semakin rendah pula Kreativitas Guru. 
Besarnya sumbangan atau kontribusi variabel Supervisi Kepala Sekolah dan Iklim Organisasi secara bersama-sama dapat diketahui melalui nilai koefisien determinasi $\mathrm{r}_{\mathrm{y} 12}^{2}=$ 0,8464. Hasil analisis tersebut menunjukkan bahwa lebih kurang 84,64 persen variasi perubahan Kreativitas Guru ditentukan/dijelaskan oleh Supervisi Kepala Sekolah dan Iklim Organisasi secara bersama-sama dengan pola hubungan fungsionalnya seperti ditunjukkan oleh persamaan regresi tersebut di atas.

Artinya jika seluruh guru PNS di SDN Gugus 3 Kecamatan Pancoran Mas Kota Depok diteliti tentang Supervisi Kepala Sekolah dan Iklim Organisasi secara bersama-sama dengan melihat Kreativitas Gurunya, maka variasi pasangan skor ketiga variabel akan mengikuti pola persamaan regresi $\hat{Y}=122,44+0,06 X_{1}+0,08 X_{2}$.

\section{SIMPULAN}

Berdasarkan analisis terhadap data hasil penelitian dapat disimpulkan terdapat hubungan positif sangat signifikan antara supervisi kepala sekolah dengan kreativitas guru, antara iklim organisasi dengan kreativitas guru dan antara supervisi kepala sekolah dan iklim organisasi bersama-sama dengan kreativitas guru. Berdasarkan hasil penelitian ini maka untuk meningkatkan kreativitas guru dapat dilakukan dengan meningkatkan supervisi kepala sekolah dan perbaikan pada iklim organisasi.

\section{DAFTAR PUSTAKA}

Ahmad Mathori. 2007. Manajemen Perubahan dan Manajemen Harapan, Jakarta: PT Gramedia Pustaka Utama.

Boardman, C. H, Haris, J. E. 2011. TNM and FIGO Classifications for Cervical Cancer.

Colquitt, J.A., J. Lepine, M.J. Wesson. 2011. Organizational Behavior, New York: McGraw-Hill.

Conny R. Semiawan. 2009. Kreativitas dan Keberbakatan Jakarta: PT. Indeks,

Cushway, Barry dan Lodge Derek. 2004. Organizational Behavior and Design, New Delhi: Crest Publishing House.

Dadang Suhardan. 2010. Supervisi Profesional (Layanan Dalam Meningkatkan Mutu Pembelajaran Di Era Otonomi Daerah), Bandung: Alfabeta.

E. Mulyasa. 2007. Menjadi Guru Profesional menciptakan Pembelajaran Kreatif dan Menyenangkan. Bandung : Rosdakarya.

Edi Sutrisno. 2011. Budaya Organisasi, Jakarta: Kencana.

Gibson, J.L., J.M. Ivancevich, J.H. Donnelly, Jr., and R. Konopaske. 2008. Organization: Behavior, Structure and Processes. New York: McGraw-Hill.

Hani T. Handoko. 2003. Manajemen Sumber Daya Manusia. Jakarta: LP3ES.

Hellriegel, Don and John W.Slocum, Jr. 2011. Organizational Behaviour, Mason OH: South-Western Cengange Learning.

Hendyat Soetopo. 2010. Kepemimpinan dan Supervisi Pendidikan, Jakarta: Bina Aksara.

Hick, R. Gary. 2003. Organizational Behavior, Eleventh Edition. New York: McGraw Hill.

Hosseini, Afzal Sadat. 2014. The Effect of Creativity Model for Creativity Development in Teachers. International Journal of Information and Education Technology, Vol. 4, No. 2, April 2014.

Husein Umar.2004. Metode Penelitian untuk Skripsi dan Tesis, Jakarta: Rajawali.

Jeffrey, Bob and Craft, Anna. 2004. Teaching creatively and teaching for creativity: distinctions and relationships. Educational Studies, 30(1) pp. 77-87.

Kartini Kartono. 2006. Pemimpin dan Kepemimpinan, Jakarta: PT. Grafindo Persada. 
M. Ngalim Purwanto. 2005.Administrasi dan Supervisi Pendidikan, Bandung: Remaja Rosdakarya. 